\title{
TRANSPARENCY OF (PRE-)CONTRACTUAL INFORMATION IN CONSUMER CREDIT AGREEMENTS: IS CONSISTENCY THE MISSING KEY?
}

\author{
Mia Junuzović ${ }^{*}$
}

\begin{abstract}
Summary: This article shows that there is a lack of consistency in the interpretation of the meaning and scope of the obligation of traders to provide transparent pre-contractual and contractual information on consumer credit to consumers in EU law. On the basis of an analysis of transparency requirements prescribed by the Unfair Contract Terms Directive and the Consumer Credit Directive, differences in the understanding of transparency are highlighted. While the transparency test under the Unfair Contract Terms Directive focuses on the question of comprehensibility of credit information, the transparency test under the Consumer Credit Directive focuses on the format, position, length and font size of information. Consequently, the transparency of the same information provided in the course of concluding a consumer credit agreement could be evaluated differently on the basis of these two directives.
\end{abstract}

This lack of consistency in the interpretation of transparency might pose a particular problem for national enforcement authorities. In the example of Croatia, it is demonstrated that the lack of guidance and consistency in the interpretation of various transparency requirements in the area of consumer credit at the EU level leaves space for national enforcement authorities to develop their own understanding of transparency. Where national enforcement authorities develop a narrower approach to transparency, consumers can be deprived of the protection guaranteed by EU law. In areas such as consumer credit, where the obligation of the transparent provision of information is the main tool of consumer protection and market integration, ensuring greater consistency in the interpretation of the content of this obligation is the key to ensuring its effectiveness.

\footnotetext{
* Mia Junuzović, PhD candidate at the Centre for the Study of European Contract Law, University of Amsterdam; member of the Ius Commune Research School; email: M.Junuzovic@uva.nl; https://orcid.org/0000-0003-3768-7603. This paper has been prepared within the research project 'The ABC of Online Disclosure Duties: Towards a More Uniform Assessment of the Transparency of Consumer Information in Europe' funded by an Open Research Area grant (project number 464-15-192). I would like to thank Dr Joasia Luzak for her insightful comments on an earlier draft of this paper. DOI: 10.3935/ cyelp.14.2018.310.
} 


\section{Introduction}

Since the beginning of the creation of consumer law and policy at the level of the European Union (EU), the obligation of traders to provide information to consumers has been one the most prominent tools of consumer protection at the EU level. ${ }^{1}$ This is because EU consumer law is built on the ideas that a) consumers are, due to information asymmetry, weaker parties vis-à-vis businesses, and b) their behaviour on the market can be affected by information. ${ }^{2}$ Regardless of the fact that reliance on disclosure as the main instrument of consumer protection, especially in complex sectors like finance, has been heavily criticised, ${ }^{3}$ the European legislator is not yet willing to let go of this tool. On the contrary, over the years, information lists contained in various instruments of consumer law have only become longer and more detailed. ${ }^{4}$

At the same time, the European legislator became aware that not all information benefits consumers. Information that is incorrect, inconsistent, overly technical or lengthy will not enable consumers to make a

\footnotetext{
${ }^{1}$ The right to information and education was recognised as one of the five basic rights of consumers as early as in 1975, when the first consumer policy document was adopted at the EU level (point 3 of the Preliminary programme of the European Economic Community for a consumer protection and information policy [1975] OJ C92/2). The currently applicable Consumer Agenda, which was adopted in 2012, sees information as one of the main tools of consumer empowerment, and emphasises the need of consumers for quality information on goods and services (points 3.3. and 4.2. of COM (2012) 225: Communication from the Commission to the European Parliament, the Council, the Economic and Social Committee and the Committee of Regions: 'A European Consumer Agenda - Boosting confidence and growth'). See also Martien Schaub, 'How to Make the Best of Mandatory Information Requirements in Consumer Law' (2017) 25(1) European Review of Private Law 25, 26-27; Marco BM Loos, 'Double Dutch: On the Role of the Transparency Requirement with Regard to the Language in Which Standard Contract Terms for B2C-contracts Must Be Drafted' (2017) 6(2) Journal of European Consumer and Market Law 54, 54-55.

2 Vanessa Mak, 'The Myth of the "Empowered Consumer": Lessons from Financial Literacy Studies' (2012) 1(4) Zeitschrift Für Europäisches Unternehmens- Und Verbraucherrecht 254, 256-258; Michael Faure and Hanneke Luth, 'Behavioural Economics in Unfair Contract Terms' (2011) 34(3) Journal of Consumer Policy 337, 350-351; Thomas Wilhelmsson and Christian Twigg-Flesner, 'Pre-contractual Information Duties in the acquis communautaire' (2006) 2(4) European Review of Contract Law 441, 449-452; Geraint Howells, 'The Potential and Limits of Consumer Empowerment by Information' (2005) 32(3) Journal of Law and Society 349, 349-351.

${ }^{3}$ Geraint Howells and Thomas Wilhelmsson, 'EC Consumer Law: Has It Come of Age?' (2003) 28(3) EL Rev 370, 380-382; Howells (n 2) 356-362; Thomas Wilhelmsson, 'Cooperation and Competition Regarding Standard Contract Terms in Consumer Contracts' (2006) 17(1) European Business Law Review 49, 50-54; Omri Ben-Shahar and Carl E. Schneider, 'The Failure of Mandated Disclosure' (2011) 159(3) University of Pennsylvania Law Review 647, 665-667; Oren Bar-Gill and Omri Ben-Shahar, 'Regulatory Techniques in Consumer Protection: A Critique of European Consumer Contract Law' (2013) 50 CML Rev 109, 116-119; Omri Ben-Shahar and Carl E Schneider, 'The Futility of Cost-Benefit Analysis in Financial Disclosure Regulation' (2014) 43(S2) The Journal of Legal Studies 253, 258-262.

${ }^{4}$ Schaub (n 1) 26-27.
} 
rational transactional decision. On the contrary, it might prevent them from choosing the offer most suitable to their needs. ${ }^{5}$ For these reasons, traders are now required to provide consumers with transparent information on the goods or services they offer. As in other areas of law, ${ }^{6}$ transparency has become the imperative in European consumer law. Traders are obliged to provide consumers with 'clear and comprehensible', 'clear, comprehensible and prominent', ${ }^{8}$ or 'clear, concise and prominent'9 information. While it is impossible to overlook the ever-growing presence and variety of transparency requirements in European consumer law, ${ }^{10}$ it is hardly possible to establish their meaning with certainty. This is because the legal instruments prescribing transparency requirements for consumer information usually do not define their meaning and scope and, thus far, European institutions have not provided an overarching interpretation of transparency.

In the absence of an EU-wide understanding of what the obligation to provide transparent consumer information entails, national enforcement authorities have space to develop different understandings of transparency, which could deprive this regulatory tool of any effectiveness. In European consumer law, transparency is envisaged as a twofold tool; it aims to strengthen the Internal Market and ensure a high level of consumer protection. ${ }^{11}$ Through the harmonisation of rules on the transparent provision of information, the European legislator seeks to

\footnotetext{
${ }^{5}$ According to George Akerlof's Lemon Market Theory, the presence of information asymmetry between sellers and buyers can have an adverse impact on the quality of goods and services offered on the market. Namely, due to information asymmetry, buyers cannot assess the quality of goods and services offered by the sellers, which incentivises the sellers to present their goods and services as being of higher value than they actually are. However, because buyers are aware of this, when deciding whether to purchase, they will take the average quality of the goods and services on the market into consideration. As a result, high-quality goods and services will be driven out of the market since they will only sell for average quality goods and services. See George A Akerlof, 'The Market for "Lemons": Quality Uncertainty and the Market Mechanism' (1970) 84(3) The Quarterly Journal of Economics.

${ }^{6}$ For a conceptual analysis of transparency and its role in different areas of law, see Ida Koivisto 'The Anatomy of Transparency: The Concept and Its Multifarious Implications' 2016/09 EUI Working Paper MWP, available at http://cadmus.eui.eu/handle/1814/41166 (accessed 29 October 2018).

7 Art 6(1) Directive 2011/83/EU of the European Parliament and of the Council of 25 October 2011 on consumer rights [2011] OJ L304/64 (CRD).

8 Art 5(3) of Directive (EU) 2015/2302 of the European Parliament and of the Council of 25 November 2015 on package travel and linked travel arrangements [2015] OJ L326/ 1 (PTD).

${ }^{9}$ Art 11(2) of Directive 2014/17/EU of the European Parliament and of the Council of 4 February 2014 on credit agreements for consumers relating to residential immovable property [2014] OJ L60/34 (MCD).

${ }^{10}$ For an overview of various transparency requirements in European consumer law and different aspects of transparency, see Loos (n 1) 55.

${ }^{11}$ Schaub (n 1) 28-29.
} 
facilitate greater comparability of goods and services at the EU level and ensure that consumers receive information they can act upon. ${ }^{12}$ However, if these objectives are dependent on whether consumers receive an understandable set of information describing a particular good or service, it is necessary for enforcement authorities across the EU to assess information transparency in a similar manner.

This paper aims to show that, in order to be able to rely on information transparency as a tool, there is a need for (greater) consistency in the interpretation of transparency requirements. I will demonstrate the existence of such a need on the basis of a case study on the meaning and scope of transparency requirements in the area of consumer credit. This area is chosen due to its relevance. Namely, a vast number of cases on transparency of consumer information concern credit agreements. ${ }^{13}$ I will first show that there is a lack of consistent interpretation of what transparency of consumer credit information under EU law entails (part 2). In this regard, I will discuss the differences between the interpretation of transparency under the Unfair Contract Terms Directive (UCTD) ${ }^{14}$ and the Consumer Credit Directive (CCD), ${ }^{15}$ whilst both of these instruments offer essential protection to consumers concluding credit contracts. I will then analyse how this lack of consistency as to the meaning and scope of transparency impacts the way national enforcement authorities understand transparency, leading to different outcomes in practice and affecting the position of consumers (part 3). To do so, I will analyse how Croatian courts have assessed the transparency of consumer credit agreements. Croatia has been chosen as an example due to the increased litigation in this area in the past few years. ${ }^{16}$

\section{The European dimension - the Unfair Contract Terms Directive and the Consumer Credit Directive}

Until now, the transparency of information on credit agreements given to consumers by credit providers was mostly assessed on the basis of the UCTD. Cases relevant for the interpretation of the meaning and scope of the UCTD's transparency requirements include both mortgage

\footnotetext{
12 ibid.

${ }^{13}$ Hans-W Micklitz and Norbert Reich, 'The Court and Sleeping Beauty: The Revival of the Unfair Contract Terms Directive (UCTD)' (2014) 51(3) CML Rev 771, 771-772.

${ }^{14}$ Council Directive 93/13/EEC of 5 April 1993 on unfair terms in consumer contracts [1993] OJ L95/29 (UCTD).

${ }^{15}$ Directive 2008/48/EC of the European Parliament and of the Council of 23 April 2008 on credit agreements for consumers and repealing Council Directive 87/102/EEC [2008] OJ L133/66 (CCD).

${ }^{16}$ Tatjana Josipović and Hano Ernst, 'Recent Crisis-motivated Reforms in Croatian Private Law' (2015) 13(1) Evropski Pravnik 73, 82-83.
} 
and consumer credit agreements. This is not surprising considering that very specific and detailed rules on information and transparency requirements for consumer credit and mortgage agreements were adopted only recently. ${ }^{17}$

The UCTD is a minimum harmonisation directive that obliges traders to offer fair and transparent standard ${ }^{18}$ contract terms to consumers. It does so by envisaging that unfair contract terms, ie terms that, contrary to good faith, cause a significant imbalance between the parties' contractual rights and obligations, to the detriment of the consumer, ${ }^{19}$ cannot be binding on consumers. ${ }^{20}$ Also, it requires all written contract terms (including terms of consumer credit contracts) to be drafted in plain, intelligible language and ambiguous terms to be interpreted in a manner most favourable to the consumer. ${ }^{21}$ Under the UCTD, even terms regulating the contract's subject matter and price (core contract terms), which are usually exempt from unfairness assessment, are subject to transparency control. ${ }^{22}$ Core contract terms escape unfairness control due to the idea that their regulation should be subject to the will of the parties and market forces instead of judicial control. ${ }^{23}$ However, if core contract terms are not plain and intelligible, it is highly unlikely that they can genuinely be subject to the free will of the contracting parties or market competition. In this sense, as Micklitz observes, transparency control is the minimum standard the UCTD provides for. ${ }^{24}$

Like other EU directives demanding transparency, the UCTD does not define the meaning and scope of the obligation to draft contract terms in plain, intelligible language. Still, thus far, the CJEU has provided the most extensive interpretation of transparency in its case law

\footnotetext{
${ }_{17}$ In 2008, the information model for consumer credit agreements was fully harmonised at the EU level via the $\mathrm{CCD}$. EU-wide rules on mortgage credit agreements were only introduced in 2014, when the MCD was adopted.

${ }_{18}$ Art 3(1) and (2) of the UCTD stipulate that the UCTD focuses on terms that have not been individually negotiated. Additionally, Art 3(1) and (2) and Art 1(2) of the UCTD specify that all terms that have been individually negotiated, as well as terms reflecting mandatory and statutory provisions, alongside provisions of international law, fall outside its scope.

19 Art 3(1) UCTD.

${ }^{20}$ Art 6(1) UCTD.

${ }^{21}$ Art 5 UCTD.

${ }^{22}$ Art 4(2) UCTD.

${ }^{23}$ Yessim M Atamer, 'Why Judicial Control of Price Terms in Consumer Contracts Might Not Always Be the Right Answer: Insights from Behavioural Law and Economics' (2017) 80(4) Modern Law Review 624, 627-629; Michael Schillig, 'Directive 93/13 and the "Price Term Exemption": A Comparative Analysis in the Light of the "Market for Lemons" Rationale' (2011) 60(4) International and Comparative Law Quarterly 933, 937-940.

${ }^{24}$ Hans-W Micklitz, 'Reforming European Unfair Terms Legislation in Consumer Contracts' (2010) 6(4) European Review of Contract Law 347, 365-367.
} 
based on the UCTD. It should be noted here that this paper focuses on an analysis of the transparency of consumer credit agreements. However, considering that the CJEU has interpreted the UCTD's transparency requirements in the same manner with regards to mortgages and consumer credit, several cases relevant for the depiction of transparency under the UCTD are referred to, including mortgage cases. ${ }^{2526}$

As of 2008, the provision of information on consumer credit has been extensively regulated at the EU level via the CCD. Although this is the second directive regulating consumer credit at the EU level, ${ }^{27}$ the CCD for the first time fully harmonised the information regime applicable to consumer credit contracts and established the said regime as its main tool of consumer protection. ${ }^{28}$ The amount and content of information that needs to be disclosed by credit providers varies depending on the stage of the (pre-) contractual process. ${ }^{29}$ In this regard, three stages, namely the stage of advertising, the pre-contractual stage, and the contractual stage, can be distinguished. ${ }^{30}$ For each stage, the European legislator prescribed a separate, minimum list of mandatory information that has to be disclosed to consumers. For example, credit providers are generally $^{31}$ required to provide consumers with 19 pieces of information

\footnotetext{
${ }^{25}$ For example, while Case C-26/13 Kásler ECLI:EU:C:2014:282 concerned a mortgage credit agreement (para 20), Case C-348/14 Bucura ECLI:EU:C:2015:447 concerned consumer credit (para 19) and Case C-186/16 Andriciuc ECLI:EU:C:2017:703 both mortgage and credit agreements (para 8), the CJEU provided the same guidance on the meaning of the UCTD's transparency requirements in all cases (Kásler, para 75; Bucura, para 54; Andriciuc, para 45).

${ }^{26}$ The Spanish mortgage cases are excluded from this analysis due to the fact that they deal with the question of how a breach of transparency is sanctioned, whereas this article focuses on an analysis of what (a breach of) transparency entails. For an account of certain procedural aspects of the enforcement of the UCTD, see for instance Frederico Della Negra, 'The Uncertain Development of the Case Law on Consumer Protection in Mortgage Enforcement Proceedings: Sánchez Morcillo and Kušionová' (2015) 52(4) CML Rev, or Anna van Duin, 'Metamorphosis? The Role of Article 47 of the EU Charter of Fundamental Rights in Cases Concerning National Remedies and Procedures Under Directive 93/13/EEC' (2017) 6(5) Journal of European Consumer and Market Law.
}

${ }^{27}$ The first directive regulating the said area was Council Directive 87/102/EEC of 22 December 1986 for the approximation of the laws, regulations and administrative provisions of the Member States concerning consumer credit [1987] OJ L42/48 (1987 CCD). It was a minimum harmonisation directive representing the EU's first attempt in ensuring greater transparency of contract terms in the area of consumer credit, by providing some information on its costs and conditions (Iris Benöhr, EU Consumer Law and Human Rights (OUP 2013) 113-114).

${ }^{28}$ Benöhr (n 27) 116-119; Stefan Grundmann and Christian Hofmann, 'EC Financial Services and Contract Law: Developments 2007-2010' (2010) 6(4) European Review of Contract Law 467, 478-479.

${ }^{29}$ Benöhr (n 27) 117.

30 ibid.

${ }^{31}$ The CCD envisages a 'lighter' information regime for overdrafts and other specific credit agreements. The information list for such agreements is provided in Article 6(1) CCD and 
by means of a standardised information notice prior to the conclusion of the contract. ${ }^{32}$ Once the credit agreement has been concluded, it needs to contain at least 22 pieces of information. ${ }^{33}$ It should be pointed out that none of these information lists are exhaustive. This is because credit providers are either allowed to provide consumers with additional information under the $\mathrm{CCD}^{34}$ or are obliged to do so under other legislation. ${ }^{35}$

The European legislator does not, however, merely regulate the amount and content of information requirements for consumer credit agreements in the CCD. Information requirements are also accompanied by transparency requirements. For instance, information on advertising on consumer credit has to be provided in a 'clear, concise and prominent way by means of representative example'. ${ }^{36}$ Or, mandatory pre-contractual information on consumer credit agreements in principle has to be provided in an information notice, standardised at the EU level. ${ }^{37}$ Information included in consumer credit agreements has to be "clear and concise'. ${ }^{38}$ Thus, looking at various provisions of the CCD containing information and transparency requirements, the following modalities of transparency can be observed: clarity, conciseness, prominence, and information standardisation.

It can be observed that the UCTD and the CCD impose different transparency requirements for consumer credit information. If these requirements are also interpreted in a different manner, the transparency of the same information provided in the course of the conclusion of the same consumer credit agreement could be evaluated differently. Thus, in order to establish to what extent this is the case and what the consequences of such interpretation are, I will now turn to an analysis of the

still contains 14 pieces of information. Another situation in which the provision of information that occurs before the contract's conclusion is reduced (but in this case significantly) is where a credit agreement is concluded by means of distance communication, at the consumer's request, and the medium of distance communication does not allow for full disclosure. With the exception of contracts concluded by voice telephony communication, in cases of contracts concluded by means of distance communication, Articles 5(3) and 6(7) $\mathrm{CCD}$ envisage that the credit provider has to provide information immediately after the contract has been concluded. In the case of voice telephony communication, Article 5(2) CCD prescribes a minimum of five pieces of information that have to be disclosed in general, and Article 6(4) CCD prescribes a minimum of four pieces of information that have to be disclosed in the case of overdrafts and other special credit agreements.

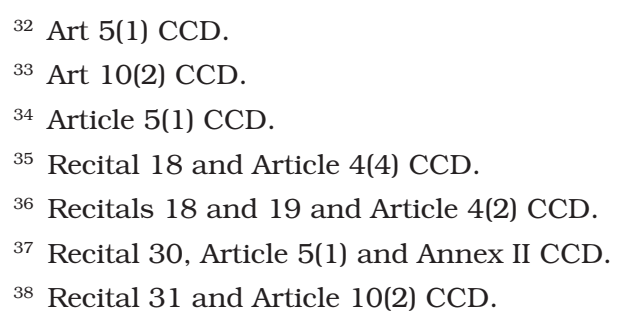


meaning and scope attributed to transparency requirements under each directive.

\subsection{Transparency under the UCTD - plainness and intelligibility}

Although the UCTD has been in force since 1993, its interpretation became the subject of an increased number of preliminary references only as of 2008. ${ }^{39}$ As Micklitz and Reich point out, the increased UCTDbased litigation concerned sectors which are particularly burdensome for consumers, like energy, telecommunications and finance. ${ }^{40}$ Even though it is not certain what triggered such an increase in the number of preliminary references, considering their timing and content they could at least to some extent be the reflection of the economic crisis in Europe. ${ }^{41}$

Among these references, questions regarding the interpretation of the trader's obligation to provide transparent contract terms occupy a prominent place. The case law on the meaning and scope of the UCTD's transparency requirements has been actively developing as of 2012, starting with cases concerning the transparent provision of information on contract terms that allow unilateral adjustments of costs by traders in long-term contracts. The first cases of this kind concerned telecommunication and energy contracts ${ }^{42}$ and showed that traders are obliged to inform consumers of the existence, the reasons for and the method of calculation of unilateral adjustments of contractual costs. ${ }^{43}$ In order to effectively inform consumers on these matters, traders have the duty to formulate contract terms in a manner that will allow consumers to foresee, on the basis of clear, intelligible criteria, changes which will stem from them. ${ }^{44}$ In my view, these cases clearly explicated the purpose of the UCTD's transparency requirements - ensuring that consumers are able to foresee the outcome of the contract.

The CJEU's case law shows that this reasoning, although originally developed in other sectors, also applies to credit agreements. ${ }^{45}$ In this

\footnotetext{
${ }^{39}$ Hans-W Micklitz and Norbert Reich (n 13) 771.

40 ibid, 771-772.

41 ibid.

${ }^{42}$ Case C-472/10 Invitel ECLI:EU:C:2012:242 concerned telecommunication whilst Case C-92/11 RWE Vertrieb ECLI:EU:C:2013:180 concerned energy. Given that the topic of this paper is limited to credit contracts, these cases are not discussed here. For a critical account of the role of transparency in the aforementioned cases, see Candida Leone, 'Transparency Revisited: On the Role of Information in the Recent Case-law of the CJEU' (2014) 11(1) European Review of Contract Law.

${ }^{43}$ Invitel (n 42) para 24-31; RWE Vertrieb (n 42) para 49-54.

${ }^{44}$ Invitel (n 42) para 28; RWE Vertrieb (n 42) para 49.

${ }^{45}$ Kásler (n 25) para 73; Case C-143/13 Matei ECLI:EU:C:2015:127, para 74; Bucura (n 25) para 54.
} 
regard, the Matei case can be used as an example. This case concerned terms of a mortgage and a consumer credit agreement that allowed for unilateral adjustment of the interest rate by the bank. ${ }^{46}$ In line with previous case law, the CJEU made it clear that, for the purpose of compliance with the UCTD's transparency requirements, the national court must determine whether the credit agreements transparently set out the reasons for and the mechanism of alteration of the interest rate, thereby enabling the consumer to foresee the consequences of the contracts. ${ }^{47}$

In the next stage of development of the case law on transparency, the CJEU provided more guidance as to what it actually means to provide information in a manner that is understandable to consumers. This was done in 2014 in the Kásler case, where the CJEU for the first time explicitly interpreted the requirements of plainness and intelligibility. ${ }^{48}$ The case in question dealt with a mortgage agreement denominated in a foreign currency (Swiss Franc) but payable in the domestic currency (Hungarian Forint). ${ }^{49}$ The disputed contract term enabled the bank to unilaterally determine the amount of monthly instalments that had to be paid in Hungarian Forints on the basis of its selling rate for Swiss Francs. ${ }^{50}$ Since the term in question seemed to constitute a core contract term, ${ }^{51}$ before being able to assess its fairness, the national court had to evaluate whether it was drafted in plain, intelligible language. To do so, the national court found it necessary to first ask the CJEU whether the meaning of the UCTD's transparency requirements stretches beyond the obligation to provide consumers with formally and grammatically intelligible contract terms. ${ }^{52}$

The CJEU explained that the requirement of transparency had to be interpreted in a broad sense - demanding that contract terms be formulated in a manner that makes them both formally and grammatically intelligible and reveals their economic consequences. ${ }^{53}$ The CJEU opted for a broad interpretation of transparency for two reasons. First, the court in question took the view that consumers decide whether to enter into a contract on the basis of information they have been provided with on its terms. ${ }^{54}$ Second, it emphasised that the UCTD's system of protection

\footnotetext{
${ }^{46}$ Matei (n 45) paras 24-26.

47 Matei (n 45) para 74.

${ }^{48}$ Kásler (n 25) paras 69-74.

49 ibid, paras 20-22.

50 ibid, para 24.

51 ibid, para 86.

52 ibid, para 33.

53 ibid, paras 71-75.

54 ibid, para 70.
} 
is based on the idea that consumers are in a weaker position vis-à-vis traders, in particular with regards to their knowledge. ${ }^{55}$

Applied to the contested contract term in Kásler, which allowed the bank to calculate the amount of monthly instalments payable by the consumer on the basis of its selling exchange rate of foreign currency, this meant that the contract had to transparently provide the reason for and the particularities of the mechanism of conversion. ${ }^{56}$ It also had to specify the relationship between that mechanism and other conditions of the loan so that the consumer could foresee the economic consequences which derived for her from the contract on the basis of clear, intelligible criteria. ${ }^{57}$

In the same case, the CJEU also explained how the formal and economic intelligibility of contract terms have to be assessed. Namely, national courts are expected to assess the transparency of a credit contract term in light of all the promotional material and information given to the consumer during the contract's negotiation ${ }^{58}$ and in light of its relationship with other terms and the overall contractual framework. ${ }^{59}$ Taking into account the context in which the contract terms are provided, it must then be established whether their economic impact would be understandable to a hypothetical, average 'reasonably well-informed and reasonably observant and circumspect' consumer. ${ }^{60}$

These criteria were later repeated in multiple cases dealing with the question of transparency of terms of credit agreements, such as Matei, Bucura, Gutiérrez Naranjo and Andriciuc. ${ }^{61}$ In my opinion, these cases outlined the meaning of the UCTD's transparency requirements - the duty to provide consumers with contract terms that are understandable to them both in terms of their grammatical meaning and their economic consequences. Additionally, the cases in question established how it should be evaluated whether both of these aspects of transparency are fulfilled.

Another development in the CJEU's case law on the transparency of terms of credit agreements occurred recently, in the Andriciuc case, which was decided in 2017. In the said case, the CJEU was asked to clar-

\footnotetext{
55 ibid, paras 70-72.

56 ibid, para 73.

57 ibid, para 73.

58 Kásler (n 25) para 74; Matei (n 45) para 75; Andriciuc (n 25) para 46.

59 Kásler (n 25) para 75; Matei (n 45) para 74; Andriciuc (n 25) para 45.

60 Kásler (n 25) para 74; Matei (n 45) para 75; Andriciuc (n 25) para 47.

${ }^{61}$ Matei (n 45) paras 73-75; Bucura (n 25) paras 54-56; Case C-154/15 Gutiérrez Naranjo ECLI:EU:C:2016:980, paras 48-49; Andriciuc (n 25) para 44-47.
} 
ify if the requirement of transparency of a contractual term was limited to providing intelligible information on the reasons behind the term's incorporation in the agreement and its operation within the agreement. ${ }^{62}$ Or, whether the requirement of transparency must be understood as obliging the credit provider to explain to the consumer all possible consequences of the term which may have an impact on the total cost of the loan. ${ }^{63}$ In my view, in this case, the CJEU further clarified the actual scope of the obligation to provide transparent information on the terms of consumer credit agreements.

The Andriciuc case concerned both mortgage and consumer credit agreements, denominated and payable in Swiss Francs. ${ }^{64}$ Since consumers who entered into the contested agreements received their income in Romanian Leu, the risk of an increase in their monthly credit instalments due to the fluctuation of the Romanian Leu against the Swiss Franc was entirely borne by them. ${ }^{65}$ Consumers argued that the bank failed to transparently inform them of the severity of the exchange risk entailed by credit agreements denominated in Swiss Francs. ${ }^{66}$ This is because the bank did not explain to them that, unlike other foreign currencies, the Swiss Franc fluctuated greatly against the Romanian Leu. ${ }^{67}$

The CJEU held that the national court must evaluate whether the credit provider communicated to consumers all the information likely to affect the extent of their commitment so they could estimate the total cost of the credit. ${ }^{68}$ This evaluation of transparency of credit information seems to entail at least two inquiries. First, the national court has to inquire whether the information that was provided enabled the consumer to estimate the total cost of the credit. ${ }^{69}$ However, the national court also has to inquire whether the failure to mention information, which is essential considering the nature of the goods or services that are the subject of the agreement, prevented the consumer from estimating the credit's total cost. ${ }^{70}$

The CJEU established that the obligation to provide consumers with transparent contract terms means that they must be provided with 'suf-

\footnotetext{
62 Andriciuc (n 25) question 2 in para 17.

63 ibid.

${ }^{64}$ ibid, paras 8-9.

65 ibid, para 9.

${ }^{66}$ ibid, paras 10-11.

67 ibid.

68 ibid, para 47.

69 ibid.

70 ibid.
} 
ficient information to enable them to take prudent and well-informed decisions. ${ }^{71}$ Applied to the question of how to inform consumers of the risks of entering into credit agreements denominated in a foreign currency, the CJEU explained that such a risk has to be clear to consumers 'both at the formal and grammatical level and in terms of its actual effects'. ${ }^{72}$ Essentially, the information given to the consumer must make her aware of the possibility of fluctuation of the foreign currency and must enable her to assess the potentially significant economic impact this fluctuation could have on her financial obligations. ${ }^{73}$

Conclusively, to be considered drafted in plain and intelligible language, the terms and conditions of consumer credit agreements have to be grammatically intelligible and enable a reasonably well-informed and critical consumer to foresee and understand their actual economic effect. This means that, at least in some situations, it will not be enough to inform consumers on why a certain contract term forms part of the consumer credit agreement and how it operates within the said agreement. If this information does not enable consumers to genuinely be aware of the actual and potential costs of credit, it would likely not satisfy the UCTD's transparency requirements. This can be seen in the example of foreign currency loans, where the omission of information on how the currency's market fluctuation may possibly influence the cost of credit was considered problematic from the point of view of transparency. The latter example shows that the credit provider's information obligations with regards to the total cost of credit are understood broadly. This is because information on the costs of credit not only has to clearly outline the actual total cost of credit at the time it is taken out by the consumer, but it also has to illustrate how the total cost might change due to the specific characteristics of a particular consumer credit product. As a result, in order to evaluate a contract term's transparency, enforcement authorities have to take into account the information provided by the creditor during the contract's negotiation, the information contained in the contract itself, and inquire whether any other indispensable information was omitted.

Such a broad interpretation of the obligation to provide transparent consumer credit contract terms is understandable considering that the CJEU places consumers at the centre of the UCTD's system of protection and strongly embraces the information paradigm. Transparen-

${ }^{71}$ ibid, para 51. The CJEU continued with the same line of reasoning in its most recent judgment in Case C-51/17 OTP Bank and OTP Faktoring ECLI:EU:C:2018:750 (para 78) on the transparency of information regarding loans denominated in a foreign currency delivered on 20 September 2018.

72 ibid.

${ }^{73}$ ibid. 
cy is in principle used as a double tool under the UCTD, as it is used both to eliminate unfair terms from the market ${ }^{74}$ and to protect consumers. ${ }^{75}$ However, in my view, the CJEU's current case law on transparency based on the UCTD places stronger emphasis on consumer protection than on market strengthening. The CJEU has been consistently emphasising that the UCTD's system of protection is a system of protection of the weaker party, ie the consumer. ${ }^{76}$ It has also expressed the belief on numerous occasions that consumers decide whether to enter into a contract on the basis of the information on its terms and conditions that they received prior to the contract's conclusion. ${ }^{77}$ Taking into account the ideas that the consumer's weaker position is caused by a lack of knowledge and bargaining power which is meant to be improved by means of information, it is not surprising that transparency is understood broadly under the UCTD. Yet, it is questionable whether the same broad approach would be justified from the perspective of market-strengthening. If information transparency is assessed on a case-by-case basis, with a strong emphasis on consumer protection, this might limit the extent to which information on consumer credit can be standardised. Namely, if the transparency test is limited to the information actually provided by the creditor in the course of the (pre)-contractual process, it would be easier to standardise such information. Once the transparency test is understood in a broad sense and also embodies checking whether important information is omitted, this restricts the possibility to fully standardise information on consumer credit.

\subsection{Transparency under the CCD - clarity, conciseness, prominence and information standardisation}

In 2012, the European Commission (EC) provided some guidance on how the requirements of clarity, conciseness and prominence could possibly be interpreted. ${ }^{78}$ Although this guidance is not binding, it is supposed to serve for information purposes and as such is likely to in-

\footnotetext{
${ }^{74}$ Case C-473/00 Cofidis ECLI:EU:C:2002:705, para 32.

${ }^{75}$ Case C-484/04 Caja de Ahorros ECLI:EU:C:2010:309, para 27.

${ }^{76}$ ibid; Kásler (n 25) paras 39-40; Bucura (n 25) para 52; Matei (n 45) para 51; Andriciuc (n 25) para 44.

77 RWE Vertrieb (n 42) para 44; Case C-226-12 Constructora Principado ECLI:EU:C:2014:10, para 25; Kásler (n 25) para 70; Case C-96/14 Van Hove ECLI:EU:C:2015:262, para 41; Bucura (n 25) para 51; Matei (n 45) para 74-75; Gutiérrez Naranjo (n 61) para 50. See also Thomas Wilhelmsson and Chris Willett, 'Unfair Terms and Standard Form Contracts' in Geraint Howells, Iain Ramsay, Thomas Wilhelmsson and David Kraft (eds), Handbook of Research on International Consumer Law (Edward Elgar Publishing Limited 2010) 161.
}

${ }^{78}$ Commission Staff Working Document, 'Guidelines on the application of Directive 2008/48/EC (Consumer Credit Directive) in relation to costs and the Annual Percentage Rate of charge' SWD (2012) 128 final (Guidelines on the application of the CCD). 
fluence the manner in which national enforcement authorities interpret the CCD's transparency requirements. The meaning of the requirements of clarity, conciseness and prominence is explained in the context of advertising consumer credit. In the said context, in order to be clear, information 'should not be difficult to find, nor should it be hidden among other information'. ${ }^{79}$ To be concise, the information on the credit offer should not include 'lengthy or rambling descriptions'. ${ }^{80}$ And in order to be prominent, the information on the credit offer should be 'in text which is not too small or too difficult to read relative to other text in the advertisement'. ${ }^{81}$

As previously explained, the CCD generally requires credit providers to disclose pre-contractual information regarding credit agreements to consumers via the Standardised European Consumer Credit Information form (SECCI). ${ }^{82}$ The guidance provided by the EC seems to suggest that the European legislator views the SECCI as an information notice embodying the requirements of clarity, conciseness and prominence. When highlighting the fact that all mandatory pre-contractual information on consumer credit has to be provided via an SECCI, whilst any additional information has to be given in a separate document, the EC explained that this is to "guarantee the prominence, clarity and conciseness of the standard information as distinct from any other additional information'. ${ }^{3}$

Behavioural studies have recognised standardisation as a mode of increasing the transparency of information that has to be disclosed to consumers. ${ }^{84}$ Research shows that the manner in which the information is presented is capable of affecting consumers' comprehension. ${ }^{85}$ Additionally, many experiments have shown that consumers benefit from the presentation of information in a uniform manner because such presentation allows them to compare offers available on the market more easily. ${ }^{86}$ This also seems to be one of the main reasons why the European

\footnotetext{
${ }^{79}$ Guidelines on the application of the CCD (n 78) 11.

80 ibid.

81 ibid.

${ }^{82}$ Article 5(1) CCD.

${ }^{83}$ Guidelines on the application of the CCD (n 78) 12.

${ }^{84}$ Faure and Luth (n 2) 338; David Horton, 'Flipping the Script: Contra Proferentem and Standard Form Contracts' (2009) 80(2) University of Colorado Law Review 431, 473 , 484-485.

${ }^{85}$ Maartje Elshout, Millie Elsen, Jorna Leenheer, Marco Loos and Joasia Luzak, 'Study on Consumers' Attitudes Towards Terms and Conditions (T\&Cs)' 96-103<https://ec.europa.eu/ info/sites/info/files/terms_and_conditions_final_report_en.pdf> accessed 29 October 2018.

${ }^{86}$ Akos Rona-Tas and Alya Guseva, 'Information and Consumer Credit in Central and Eastern Europe' (2013) 41(2) Journal of Comparative Economics 420, 428.
} 
legislator turned to standardisation, along with the aim of reducing the complexity of information in the area of consumer credit. ${ }^{87}$

Considering that the EC, the institution that tailors proposals for European policy and legislation, claims to be relying on insights from behavioural studies in policy-making, one might think that the design of the SECCI has been informed by behavioural research. Still, the CCD's travaux préparatoires suggest that the SECCI is merely a product of political compromise between two conflicting groups of Member States - one wanting to disclose as much information on credit as possible and the other wanting to disclose only essential information. Once an understanding on the content and amount of mandatory information is reached, this information is divided into separate categories on the basis of a common denominator. Consequently, information on, for instance, the type of credit, total amount, duration, etc, has to be provided within the section 'Description of the main features of the credit product', whilst information on the borrowing rate, the APR, etc, needs to be included in 'Costs of the credit'.

In my view, it is entirely unclear how merely ensuring that only mandatory pre-contractual information on consumer credit agreements is provided by means of an SECCI automatically guarantees the clarity, conciseness and/or prominence of the said information. In the form in which it is annexed to the CCD, the SECCI is a blank notice that has to be filled in by the credit provider. It does not in any way guarantee that information will be filled in by the credit provider in a clear, concise and prominent manner. When filling in an SECCI, credit providers can still make it difficult for consumers to find information. For example, in providing a lot of information, they can use lengthy or rambling descriptions, or draft information in a font size or in a font style that is difficult to read. For these reasons, establishing that an SECCI was in fact given to the consumer prior to the contract's conclusion cannot be equated with the control of transparency of the information contained in the SECCI. In order to be able to conclude that the information contained in the SECCI is transparent, national enforcement authorities should still be required to check whether the SECCI was actually filled in by the credit provider in a clear, concise and prominent way.

The EC did not provide any guidance on what the requirement to draft information in a clear and concise manner entails in relation to contractual information. However, the CJEU, to some extent, interpreted this requirement in the case Home Credit Slovakia. It held that, when

${ }^{87}$ Recitals 19 and 43 CCD. See also Catherine Garcia and Willem H Van Boom, 'Information Disclosure in the EU Consumer Credit Directive: Opportunities and Limitations' in James Devenney and Mel Kenny (eds), Consumer Credit, Debt and Investment in Europe (CUP 2012) $54-55$. 
information is disclosed in more than one document, the documents in question have to contain clear and precise cross-referencing in order for the information, which should have already been given to the consumer prior to the contract's conclusion, to be included in a clear and concise manner. ${ }^{88}$ It is clear from the CJEU's reasoning in the said case that the purpose of these requirements is to ensure that consumers have the opportunity to become genuinely apprised of their rights and obligations under the credit agreement. ${ }^{89}$

It can be noted that none of the CCD's transparency requirements have thus far been interpreted as requiring information to be drafted in a way which ensures its comprehensibility to consumers. It is indeed important for the purposes of ensuring transparency of credit information that the said information can be easily found, that it is not too long, or drafted in a font size which is too small. Still, considering that the purpose of the CCD's information regime is to enable consumers to compare credit offers and navigate the consumer credit market, it is even more important to ensure that consumers are given intelligible information. And although the intelligibility of consumer credit information might be increased by means of standardisation, it is necessary to keep in mind that the SECCI currently does not in any way guarantee consumers will be given understandable information.

If the interpretation of the meaning and scope of the CCD's transparency requirements is compared with that of the UCTD's requirements, differences can be observed. While transparency under the UCTD has been interpreted in a manner that focuses on the comprehensibility of information, transparency under the CCD has been interpreted in a way that focuses on the format, position, length, and font size of information. As a result, the transparency of the same information provided in the course of the conclusion of a consumer credit agreement could be evaluated differently on the basis of these two directives. For instance, when assessing whether consumers could understand the economic impact of consumer credit on the basis of the UCTD, enforcement authorities are asked to examine the information that was given to consumers and consider whether other important information was omitted. Under the CCD, it looks as though it might be possible to reduce this examination to a check of whether consumers were provided with an SECCI or whether they were provided with a contract containing clear cross-referencing. What is uncertain is whether the European legislator deliberately introduced a different transparency test under the CCD and what the relationship between the two tests is.

\footnotetext{
${ }^{88}$ Case C-42/15 Home Credit Slovakia ECLI:EU:C:2016:842, para 34.

89 ibid.
} 
When providing guidance on how to interpret key notions under the CCD, the EC seems to place greater emphasis on the objective of the creation of a functioning internal market in consumer credit than on the protection of consumers who enter into consumer credit. ${ }^{90}$ If this were indeed the case, a different approach to transparency would not be surprising. Namely, if the principal role of transparency under the CCD is to ensure that credit offers and agreements across the EU are as similar and comparable as possible, it makes sense that the focus of the CCD's transparency test is to check whether all mandatory credit information is provided and is provided in the right format.

It is important to note that such a transparency test would not place sufficient emphasis on the question of whether consumers understood information on consumer credit. This is problematic from the point of view of consumer protection. The CCD did not harmonise other possible tools of consumer protection such as the duty of responsible lending or the credit provider's duty to give personalised advice on credit to consumers. ${ }^{91}$ Thus, considering that the creditor's obligations to provide consumers with information on consumer credit is the principal tool of consumer protection under the $\mathrm{CCD}$, it is worrying that transparency has not yet been interpreted as also ensuring the comprehensibility of information. Ensuring that the UCTD's transparency test is applied alongside the CCD's test could solve the problem. If enforcement authorities always check both whether consumers were provided with an SECCI and whether the information contained in the SECCI was in plain and intelligible language, this could enhance the assessment of transparency of consumer credit information. Yet, at the moment this does not seem to be ensured. The transparency test under the UCTD seems to guarantee a higher level of consumer protection by demanding that consumers be given information that enables them to truly understand the economic consequences of a credit contact. Therefore, in cases where consumer credit contract terms are contested on the basis of the UCTD, consumer interests can be sufficiently safeguarded. However, in situations where litigation is based on the CCD, there is a justified worry that the transparency test could be reduced to a check regarding whether all the information prescribed by law was provided in a proper format.

${ }^{90}$ Guidelines on the application of the CCD (n 78) 2-3.

${ }^{91}$ Grundmann and Hofmann (n 28) 480-482. 


\section{The national dimension - transparency of terms and conditions of consumer credit agreements in Croatian law}

The UCTD was transposed into Croatian law via the Consumer Protection Act (CPA) in 2003, a decade before Croatia joined the EU. ${ }^{92}$ The UCTD's transparency requirements and interpretation rules are regulated in Articles 52, 53 and 54(1) CPA. ${ }^{93}$ Article 52 stipulates that it is not allowed to evaluate the unfairness of the contract's subject matter and the adequacy of price (core contract terms) if the said terms are plain, easily intelligible and noticeable. Article 53 prescribes that if, due to the law or the parties' agreement, the contract is in a written form, its terms have to be drafted in a plain and intelligible manner and be easily noticeable. Article 54(1) requires ambiguous or unintelligible terms to be interpreted in a manner more favourable to the consumer.

It can be observed that the CPA's transparency requirements differ from those under the UCTD, as the CPA adds a third transparency requirement to the European test - noticeability. Additionally, the CPA formulates the requirement of intelligibility with regards to core contract terms differently, ie it requires core contract terms to be easily intelligible. This is not necessarily problematic as the UCTD is of a minimum harmonisation character and therefore allows Member States to provide additional protection to consumers. ${ }^{94}$ However, whether and how these additional transparency requirements could enhance consumer protection is not particularly clear since the Croatian legislator failed to explain the meaning behind their introduction. ${ }^{95}$ The purpose of the requirement of noticeability could be to ensure that traders cannot hide contract terms by, for example, placing them under the wrong heading or drafting them in fine print. Requiring the terms regulating the contract's subject matter and price to be easily understandable might be aimed at guaranteeing that consumers can understand the contract's core as-

\footnotetext{
92 Zakon o zaštiti potrošača NN 96/2003 (2003 Consumer Protection Act). See also Marko Baretić, 'Zaštita potrošača u Republici Hrvatskoj nakon ulaska u Europsku Uniju - jesmo li implementacijom europskog prava izgradili sustav zaštite potrošača?' in Thierry Bourgoignie and Tatjana Jovanić (eds), Strengthening Consumer Protection in Serbia/Jačanje zašstite potrošača u Srbiji (Liber Amicorum Svetislav Taboroši 2013) 67.

${ }_{93}$ Zakon o zaštiti potrošača NN 41/14, 110/15 (2014 Consumer Protection Act).

${ }^{94}$ Commission Staff Working Document, 'Report of the Fitness Check on Directive 2005/29/ EC, Council Directive 93/13/EEC, Directive 98/6/EC, Directive 1999/44/EC, Directive 2009/22/EC and Directive 2006/114/EC' SWD (2017) 209 final 8.

${ }_{95}$ Documents pertaining to the adoption of the 2007 Consumer Protection Act (Zakon o zaštiti potrošača NN 79/2007), which initially formulated the transparency requirements in this manner, can be found here <http://edoc.sabor.hr/Views/AktView.aspx?type=HTML\&id=7834> (accessed 29 October 2018). Documents pertaining to the adoption of the 2014 Consumer Protection Act can be found here <http://edoc.sabor.hr/Views/AktView. aspx?type=HTML\&id=25872> (accessed 29 October 2018).
} 
pects with ease and without having to ask a professional for additional explanations.

Still, it is questionable whether there is a need for different transparency requirements in order to make sure that contract terms are visible and understandable to laypersons. For instance, ensuring the visibility of contract terms could fall within the requirement of plainness, and ensuring their comprehensibility to the layperson could fall within the requirement of intelligibility. Nonetheless, the Croatian legislator could have made the additions in question not being sure whether these aspects of transparency would be covered under EU law. This is because there were no guidelines by the European legislator or the CJEU on the meaning and scope of the UCTD's transparency requirements at the time of the UCTD's transposition into Croatian law.

Although the Croatian legislator did not provide guidance on the meaning of plainness, noticeability and intelligibility, Croatian courts have interpreted all three of the above-mentioned requirements in relation to mortgage and consumer credit agreements. The case law in this field started rapidly developing as of 2012, when a consumer organisation, 'Potrošač - Hrvatski savez udruga za zaštitu potrošača' (Potrošač), started judicial proceedings against several banks (the Franak case) for the infringement of the collective interests of consumers. ${ }^{96}$ The Franak case deals with the questions of transparency and unfairness of two types of contract terms, namely, terms indexing credit agreements to the Swiss Franc (currency clauses) and terms envisaging a variable interest rate (variable clauses). ${ }^{97}$ Currency clauses allowed banks to tie the value of the contractual obligation to a foreign currency. This was a widespread practice in Croatia that owed its popularity to the perceived instability of the national currency, the Croatian Kuna. ${ }^{98}$ Since its introduction, the Croatian National Bank first pegged the Kuna to the German Mark and, after the latter ceased to exist, the Euro. ${ }^{99}$ Pegging the national currency to a stable, foreign one was meant to preserve the obligation's real value and protect both the bank and the consumer. ${ }^{100}$ For these reasons, it was perceived safer and was thus more popular to save and take out loans in foreign currencies such as the German Mark, Euro and Swiss Franc. However, while maintaining the stability of the Kuna in relation to the Euro was and is an official policy of the Croatian National Bank, no such protection of the relationship between the Kuna and the Swiss Franc

\footnotetext{
96 Judgment P-1401/2012 of the Commercial Court of 4 July 2013, 1.

97 ibid 9.

98 Josipović and Ernst (n 16) 78-79.

99 ibid.

100 Judgment Revt-249/14 of the Supreme Court of 9 April 2015, 18-19.
} 
ever existed. Therefore, it was significantly riskier to enter into credit agreements indexed to the Swiss Franc than those indexed to the Euro. Variable clauses allowed banks to unilaterally adjust interest rates. ${ }^{101}$ In some cases, the criteria on the basis of which interest rates could change would be prescribed in the bank's general terms and conditions. ${ }^{102}$ In other cases, the said criteria would be established by a decision of the bank's management after the contract had already been concluded. ${ }^{103}$

The Franak case concerns both mortgage and consumer credit agreements, most of which were burdened by both currency and variable clauses. Due to the continuous appreciation of the Swiss Franc, which started in 2011, the value of credit instalments for loans denominated in Swiss Francs rose steeply. Consequently, many consumers were left unable to pay off their loans, which, for those who borrowed money to buy property, resulted in the loss of their home. The severity of the situation thus prompted the collective action in question. Additionally, the Franak case inspired new legislative solutions regarding informing consumers on particular aspects of consumer credit agreements, which were incorporated into the Consumer Credit Act (CCA). The CCA transposes the CCD into Croatian law and was first adopted in 2009. ${ }^{104}$ It mostly follows the letter of the CCD when it comes to transparency requirements for (pre-) contractual information. ${ }^{105}$ However, the CCA also goes a step further by providing creditors with precise guidelines on how to inform consumers of their right to have loans tied to Swiss Francs converted into loans tied to the Euro ${ }^{106}$ or how to inform consumers on variable interest rates. ${ }^{107}$

In this section, I will analyse how Croatian courts interpreted the requirements of plainness, noticeability and intelligibility on the basis of the provisions of the CPA regulating unfair contract terms in the Franak case. I will rely on the same case to demonstrate how information requirements introduced under specific consumer credit legislation, namely the CCA, affected the understanding of transparency under the CPA.

\footnotetext{
${ }_{101}$ Commercial Court P-1401/2012 (n 96) 147.

102 ibid, 152, 155.

103 ibid, 147.

${ }_{104}$ Zakon o potrošačkom kreditiranju NN 75/2009, 112/12, 143/13, 147/13, 09/15, 78/15, 102/15, 52/16 (Consumer Credit Act). See also Emilia Mišćenić, 'Usklađivanje prava zaštite potrošača u Republici Hrvatskoj' (2013) 4(1) Godišnjak Akademije pravnih znanosti Hrvatske 145, 165-167.

105 Arts 4, 5, 6 and 10 of the Consumer Credit Act.

${ }^{106}$ Art 19.c and 19.d of the Consumer Credit Act.

107 Art 11.a of the Consumer Credit Act.
} 


\subsection{The Franak case - plainness, noticeability and intelligibility}

Throughout the Franak case, the requirements of plainness, noticeability and intelligibility were in principle discussed separately and it looks as though all three requirements have to be cumulatively fulfilled in order for a contract term to be considered transparent. ${ }^{108}$ The requirement of plainness was only briefly discussed in the case at hand and was associated with the term's clarity. Namely, contested clauses were considered plain because they were formulated in a manner which made it clear what their subject matter was. Currency clauses were considered plain because they explicitly and unambiguously tied the value of the credit to the Swiss Franc. ${ }^{109}$ And variable clauses were seen as plain because they explicitly indicated that interest rates were subject to change on the basis of the bank's decision. ${ }^{110}$

When discussing the requirement of noticeability, Croatian courts adjudicating in the Franak case took into account where the disputed terms were stipulated and in what style. Higher courts found it sufficient for the purposes of noticeability that contested contract terms were stipulated on the first page of all credit agreements and were not drafted in small font size. ${ }^{111}$ Unlike the said courts, the court of first instance, the Commercial Court, was of the opinion that banks should highlight complex credit contract terms in a specific way and warn consumers about the said terms. ${ }^{112}$

When interpreting the requirement of intelligibility, national courts considered the CJEU's deliberations on transparency provided in the Kásler case and inquired if consumers could have been expected to understand the economic consequences of variable clauses. ${ }^{113}$ The latter were found unintelligible to consumers by all courts adjudicating in the Franak case. All courts agreed that, in order to be intelligible, variable clauses had to specify objective criteria on the basis of which interest rates could change. ${ }^{14}$ The problem with the disputed clauses was that they either provided numerous parameters on the basis of which the said

\footnotetext{
108 Judgment Pž-7129/13 of the High Commercial Court of 13 June 2014 50-56; Supreme Court Revt-249/14 (n 100) 17-24, 33-35.

109 High Commercial Court P̌̌-7129/13 (n 108) 52; Supreme Court Revt-249/14 (n 100) 17.

110 Supreme Court Revt-249/14 (n 100) 33.

${ }^{111}$ High Commercial Court Pž-7129/13 (n 108) 52; Supreme Court Revt-249/14 (n 100) 23, 33.

112 Commercial Court P-1401/2012 (n 96) 176-177.

${ }^{113}$ High Commercial Court Pž-7129/13 (n 108) 57; Judgment U-III-2521/2015 of the Constitutional Court of 13 December 2016 31-34.

114 Commercial Court P-1401/2012 (n 96) 152; High Commercial Court Pž-7129/13 (n 108)

56-57; Supreme Court Revt-249/14 (n 100) 33.
} 
change would occur or they did not provide a single one. ${ }^{115}$ While some terms specified that interest rates could be changed on the basis of several criteria, the relationship between them was unclear, ${ }^{116}$ and others only provided that the bank would subsequently decide on the modalities of change. ${ }^{117}$ Therefore, in both scenarios, banks did not provide consumers with contract terms that established clear and objective criteria on the basis of which interest rates could change. For this reason, it was considered that consumers were not given information that would enable them to fully understand the economic consequences of variable clauses. Such a view of intelligibility mirrors the CJEU's interpretation of the UCTD's transparency requirements and thus should be considered compatible with EU law.

Unlike the question of intelligibility of variable clauses, the question of intelligibility of currency clauses was approached differently by different national courts. The first-instance court, the Commercial Court, found the currency clauses unintelligible to consumers. The Commercial Court first observed that entering into credit agreements denominated in foreign currencies generally entails significant risk, which becomes even greater the longer the contractual period is. ${ }^{118}$ It then compared the risk of entering into credit agreements denominated in a foreign currency, which is pegged to the national one, with the risk associated with concluding the same type of agreements indexed to a currency that is freely floating on the market. ${ }^{119}$ Here it held that, as long as the Croatian National Bank pegged the Kuna to the Euro, credit agreements denominated in Euro would entail significantly less risk for consumers. Contrarily (and consequently), credit agreements denominated in any other (floating) currency, including the Swiss Franc, would entail much greater risk for consumers. ${ }^{120}$ The Commercial Court noted that the banks actively advised consumers to take out loans denominated in Swiss Francs and benefited from lower interest rates instead of warning or even generally informing consumers of the risk that the currency's market fluctuation entails. ${ }^{121}$ Due to the inadequacy of the information that the banks provided on these risky clauses, ${ }^{122}$ the Commercial Court held that consumers could not have genuinely understood the currency clauses.

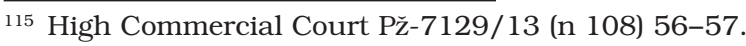

116 Commercial Court P-1401/2012 (n 96) 152, 155.

117 ibid, 147.

118 ibid, 133.

119 ibid, 133-135.

120 ibid, 135.

121 ibid, 143-147.

122 ibid, 133.
} 
Higher courts, namely the High Commercial Court and the Supreme Court, understood the issue of the intelligibility of currency clauses in an entirely different manner. Essentially, these courts found the currency clauses to be intelligible to any Croatian citizen due to the fact that they are legal and widely used in Croatian society. ${ }^{123}$ This meant that an average consumer, who is considered reasonable, informed and circumspect, should also be familiar with these clauses. ${ }^{124}$ They did not find it problematic that the banks did not sufficiently, let alone transparently, inform consumers, either pre-contractually or contractually, of the economic consequences of currency clauses. ${ }^{125}$ Such an interpretation of intelligibility was ultimately considered deficient by the Constitutional Court, which rightly observed that the mere fact that currency clauses are recognised in society does not mean that an average consumer, lacking financial knowledge, can understand their economic consequences without having been properly informed. ${ }^{126}$

The Franak case was eventually sent back to the High Commercial Court with the task to re-evaluate the transparency (and fairness) of the currency clauses. ${ }^{127}$ The aforementioned court rendered the final decision in this case in June 2018 and declared the currency clauses non-transparent. ${ }^{128}$ The High Commercial Court persisted in its finding that the currency clauses were sufficiently clear and noticeable. ${ }^{129}$ However, the said court acknowledged that it found the currency clauses sufficiently intelligible due to a narrow understanding of transparency, which differed from that adopted under EU law. ${ }^{130}$ Namely, the High Commercial Court explained that it considered the currency clauses intelligible because it assessed them only from the aspect of formal and grammatical intelligibility. It recognised that such a transparency test differs from the one required under EU law, which also entails an assessment of whether consumers could understand and foresee the economic consequences of currency clauses on the basis of the information given by the banks prior to the contract's conclusion. Adopting a broader understanding of transparency allowed the High Commercial Court to conclude that the contested currency clauses violated the requirement of transparency, which opened up the possibility of a control of their fairness.

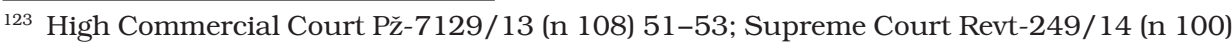
$18-24$.

${ }^{124}$ High Commercial Court Pž-7 129/13 (n 108) 52; Supreme Court Revt-249/14 (n 100) 18-19.

125 Constitutional Court U-III-2521/2015 (n 113) 32.

126 ibid, 32-33.

127 Decision Revt-575/16 of the Supreme Court from 3 October 2017 16-18.

128 Judgment Pž-6632/17 of the High Commercial Court of 14 June 2018 53-59.

129 ibid, 48-52.

130 ibid 52-53.
} 
In my opinion, this case shows that national enforcement authorities can adopt a different interpretation of the requirement of transparency of contract terms in the absence of a clear definition at the EU level. Half of the Croatian courts involved in the Franak case adopted a view of transparency which was much narrower than that developed in the case law of the CJEU. This is because the said courts focused only on the formal and grammatical aspect of the transparency requirement, without, however, inquiring whether banks provided consumers with information on currency clauses that enabled them to realise their economic effect. Additionally, as explained in the first part of this article, it stems from the CJEU's case law, including cases on foreign currency loans, that intelligibility has to be evaluated keeping in mind the circumstances of a particular case. EU law requires national enforcement authorities to examine the information that was actually given to consumers, from promotional materials and other information provided during the loan's negotiation to the information contained in the contract. This examination includes checking whether any indispensable information was omitted and whether a reasonably informed and critical consumer could have understood it. Contrary to this, some Croatian courts assessed the transparency of currency clauses in a very abstract manner, focusing on the fact that currency clauses were legal and widespread in Croatian society, which, in the view of those courts, automatically made them sufficiently intelligible to any Croatian citizen.

It should be noted that the Franak case was started in 2012 and decided in 2018. Thus, the case in question was adjudicated during the time that the CJEU's case law on the transparency of credit agreements was still developing. Furthermore, the CJEU only provided particular guidance on how to assess the transparency of currency clauses in 2017, in the Andriciuc case. Considering there was less certainty as to the meaning and scope of transparency under EU law at the time of the proceedings in the Franak case, it is not surprising that some Croatian courts understood transparency in a different, narrower manner than the CJEU.

In my view, it is important to keep in mind that the degree of protection consumers will be afforded in litigation against unfair contract terms will sometimes depend on whether the enforcement authorities adopt a narrow or broad approach to transparency. The Franak case illustrates the actual impact that different interpretations of the requirement of transparency of contract terms have on the position of consumers. For as long as Croatian courts maintained their narrow understanding of transparency and considered the currency clauses sufficiently transparent, the potential unfairness of these clauses could not be examined and they remained binding on consumers. Once the courts broadened their 
interpretation of transparency, such a change resulted in the finding that the currency clauses were not sufficiently transparent to an average consumer, which opened up the possibility of a review of their fairness. In the end, mostly due to their lack of transparency, the currency clauses were found unfair and therefore null and void. ${ }^{131}$ This finding will have a significant, positive impact on the financial situation of thousands of consumers who concluded credit agreements containing currency clauses in Swiss Francs and will now be able to seek compensation for the damage caused by these clauses.

\subsection{The Franak case and the Consumer Credit Act: the impact of the interpretation of transparency requirements across different legal acts}

As previously explained, the CCA almost entirely mirrors the CCD when it comes to the manner in which credit providers have to give information on consumer credit to consumers. However, the Croatian legislator has also prescribed in greater detail how credit providers have to inform consumers of certain aspects of consumer credit agreements under the CCA. One of the aspects of consumer credit agreements that consumers have to be informed about in a particular manner are variable clauses. In the Franak case, the Supreme Court reflected on the specific information requirements introduced under the CCA when evaluating the intelligibility of variable clauses on the basis of the provisions of the $\mathrm{CPA}$ regulating unfair contract terms. In my opinion, this is a good example of how the interpretation of transparency under one legal act can be influenced by information and transparency requirements prescribed by another legal act.

When assessing the intelligibility of variable clauses in the Franak case, the Supreme Court tested the comprehensibility of information on the reasons behind and the modalities of changes of interest rates for an average consumer. The court in question found it problematic for the purposes of intelligibility that the banks had the right to unilaterally change interest rates but failed to establish objective criteria on the basis of which the said change would occur and ensure that these criteria would be understandable to consumers. ${ }^{132}$ The Supreme Court considered the information on variable clauses that the banks made available to consumers highly technical and thus only understandable to financial experts. ${ }^{133}$ For these reasons, the said court found the majority of the disputed variable clauses unintelligible.

\footnotetext{
131 ibid, 62-66.

${ }^{132}$ Supreme Court Revt-249/14 (n 100) 33-34.

133 ibid.
} 
However, the Supreme Court was of the opinion that one bank did in fact provide consumers with understandable information on the change of interest rates in their consumer credit agreements. When evaluating the intelligibility of those contract terms, the Supreme Court compared their content with the CCA's information requirements for variable clauses, which were adopted in the course of the Franak case. ${ }^{134}$ Because the terms in question contained the information demanded under the CCA, the Supreme Court concluded that they provided clear criteria for changes of interest rates, comprehensible to consumers. ${ }^{135}$ Essentially, the Supreme Court held that the requirement of intelligibility stipulated in the CPA's provisions regulating unfair contract terms was satisfied by compliance with the CCA's information requirements for variable interest rates. This example clearly shows that even if the CJEU does not make links between information and transparency requirements in different EU directives, national courts will probably make these links when interpreting the provisions implementing the said directives. Furthermore, such an approach will likely be considered necessary to ensure consistency and certainty within the national legal order.

Looking into the provisions of the current CCA, it can be observed that credit providers offering variable interest rates are under the obligation to inform consumers in a clear and unambiguous manner of three elements. ${ }^{136}$ First, they have to define the parameter on the basis of which the variable interest rate changes. ${ }^{137}$ This parameter has to be clear and familiar to consumers. ${ }^{138}$ However, whether a certain parameter is clear and familiar to consumers will not be assessed on a case-by-case basis. Instead, it is presumed that the following parameters - EURIBOR, LIBOR, the National Reference Rate, the national treasury bond rate or the average savings rate - are clear and familiar to consumers. ${ }^{139}$ Second, creditors are obliged to qualitatively and quantitatively elaborate on how the parameter could fluctuate during the contract's duration, and how such a fluctuation would affect the level of the variable interest rate. ${ }^{140}$ Third, creditors need to determine the periods in which the change of the interest rate is considered. ${ }^{141}$ Besides informing consumers concerning

\footnotetext{
134 ibid, 25.

135 ibid.

136 Article 11.a(4) of the Consumer Credit Act. See also Josipović and Ernst (n 16) 80.

137 Article 11.a(1)(a) of the Consumer Credit Act.

138 ibid.

139 Article 11.a(2) of the Consumer Credit Act.

140 Article 11.a(1)(b) of the Consumer Credit.

${ }^{141}$ Article 11.a(1)(c) of the Consumer Credit Act.
} 
these three elements, creditors also have to warn them of all the risks that variable interest rates entail. ${ }^{142}$

In the Franak case, the Supreme Court found a term specifying that the parameter on the basis of which interest rates would change was the Swiss Franc LIBOR and that interest rates would be calculated on the basis of a proportionate-decursive method intelligible to consumers. ${ }^{143}$ By equating the requirement of intelligibility of contract terms in compliance with the information requirements under specific credit legislation, the Supreme Court failed to assess whether this kind of contract term genuinely enabled an average, informed consumer to understand its economic consequences. Both the term in question and the CCA rely on terminology that can be considered objective since it is recognised and used in finance and banking. However, this does not automatically mean that this information is or should be familiar to consumers. As Bareti rightly points out, it is hard to believe that consumers could understand very specific financial terminology without possessing or relying on expert knowledge, even in cases where this terminology is defined and explained in legal acts. ${ }^{144}$

Additionally, behavioural research consistently refutes the presumption of the familiarity of both the general public and an average, even reasonably informed and critical individual with financial terminology in practice. For instance, the Croatian National Bank's study on financial literacy has shown that only one third of Croatian citizens know how to perform complicated financial tasks, such as calculating complex interest rates. ${ }^{145}$ Thus, it is dubious whether it should be expected of consumers to be aware of the meaning and use of a parameter like LIBOR and to be able to apply, for example, the proportionate-decursive method in order to calculate complex interest rates.

Besides failing to evaluate this contract term in accordance with the transparency test applicable within the system of control of unfairness of contract terms, the Supreme Court also did not inquire whether the term in question was clear and concise, as required by specific consumer credit legislation. Namely, it failed to establish that the said term was not difficult to find, not hidden among other information or that it did not

\footnotetext{
142 Article 11.a(4) of the Consumer Credit Act.

143 Supreme Court Revt-249/14 (n 100) 24-25.

${ }^{144}$ Marko Baretić, 'Je li europsko uređenje ugovornog prava zaštite potrošača optimalni regulacijski okvir' in Jakša Barbić (ed), Zaštita potrošača u Republici Hrvatskoj (Modernizacija prava, knjiga 29 2016) 93-94.

${ }^{145}$ Hrvatska Narodna Banka and HANFA, 'Mjerenje financijske pismenosti i financijske uključenosti u Hrvatskoj' (2015) 8 <https://www.hanfa.hr/getfile/43343/Mjerenje\%20fin\%20 pismenosti\%20i\%20fin\%20uključenosti\%20u\%20RH.pdf> accessed 29 October 2018.
} 
contain lengthy or rambling descriptions, as recommended by the EC in its guidelines on the application of the CCD.

In my view, this means that the Supreme Court failed to test the transparency of at least one type of contract term in line with any of the transparency tests so far provided by European institutions in the area of consumer credit. The fact that a national court has developed its own understanding of the requirement of transparency of consumer credit agreements is not surprising. Until now, European institutions have not interpreted the requirement of transparency of consumer credit information in a consistent manner nor explained the links between the transparency requirements contained in different legal acts regulating this field. As long as this is the case, it can be expected that national enforcement authorities will continue to develop their own approach to the assessment of transparency of consumer credit contracts.

\section{Conclusion}

The obligation of businesses to provide consumers with transparent pre-contractual and contractual information on the goods and services they offer is one of the most important instruments of European consumer law. In this article, I have demonstrated the importance of this instrument in the area of consumer credit. As previously explained, it is considered that the provision of transparent information on credit offers and agreements benefits both European consumers and the Internal Market. This is because it is believed that consumers decide whether to enter into consumer credit agreements on the basis of information on the terms and conditions given by the credit provider. Thus, in order to be able to choose the credit most suitable to their needs, consumers must be able to understand credit information and compare existing credit offers. By ensuring greater transparency and comparability of consumer credit offers, the EU also aims to promote cross-border lending and to facilitate the further development of an EU-wide market in consumer credit.

However, while European institutions have shown consistency in the reliance on transparency as a tool for improving the quality and comprehensibility of consumer credit offers and agreements, they have displayed a lack of consistency in the interpretation of the meaning and scope of transparency. I have depicted this lack of consistency in interpretation of transparency by describing and comparing transparency requirements under the UCTD and the $\mathrm{CCD}$, as the position of consumers concluding credit contracts is determined on the basis of these directives. Whilst the focus of the UCTD's transparency test is to ensure the comprehensibility of information on consumer credit to consumers, the CCD's test seems to be directed towards ensuring that consumers are 
provided with certain information on credit and that this information is given in a specific format. If the two tests are compared, it looks as though their primary objectives differ.

Transparency under the UCTD is viewed as requiring creditors to provide consumers with information that is going to enable them to genuinely understand the economic consequences of a credit agreement and therefore seems to be geared more towards the protection of consumers. And since transparency under the CCD is seen as asking creditors to provide a certain amount of information, in the right format and without obscuring the said format by, for example, engaging in rambling descriptions, it might be more focused on the strengthening of the EU consumer credit market. As explained before, the UCTD's transparency test entails an evaluation of the information provided to consumers in the course of the contract's negotiation, the information included in the contract and, at least in some cases, a check on whether other indispensable information was omitted. Such a broad assessment of transparency, which includes not only examining the information that is in fact provided but also inquiring whether important information was omitted, might restrict the possibility to fully standardise credit information.

Nonetheless, out of the two tests, the one under the CCD raises more concerns. Namely, not only have none of the CCD's transparency requirements been interpreted as ensuring the comprehensibility of information to consumers, its information model also does not guarantee the standardisation of credit information and the greater transparency of credit offers. As previously pointed out, this is due to the fact that credit information does not always have to be provided on a standardised form and, even when it does, credit providers can still fill it in in different ways or can provide additional information. In order to solve this problem, at least one of the CCD's transparency requirements should be interpreted as requiring that consumers are provided with information they can genuinely understand. The problem could also be solved simply by always applying the UCTD's transparency test alongside the CCD's test. Unfortunately, this will not always be the case. The case of Home Credit Slovakia showed that even the CJEU will not necessarily apply the UCTD's transparency test ex officio if the case is litigated on the basis of the CCD. And the Franak case revealed that national courts might consider the UCTD's transparency requirements, as transposed into national law, fulfilled by mere compliance with the more specific national legislation implementing the CCD's information obligations.

Besides establishing that there is a lack of consistency as regards the interpretation of transparency in the area of consumer credit at the level of the EU, I have demonstrated that this lack of consistency can 
have an impact on the manner in which national enforcement authorities assess transparency. In the example of Croatia, I have shown how the lack of precise guidance on the meaning and scope of transparency at the European level can lead to national courts developing their own, different interpretation of transparency. This is problematic in cases where national enforcement authorities adopt a narrower understanding of transparency than the CJEU, since such an understanding of transparency can have an adverse effect on the rights of EU consumers. Additionally, even if European institutions do not explain the links between various transparency requirements in different $\mathrm{EU}$ directives, national enforcement authorities will probably make these links when interpreting national law transposing EU legislation to ensure consistency and certainty within the national legal order. Therefore, in areas like consumer credit, where information transparency is used as the main tool of consumer protection and market integration, greater consistency in the interpretation of transparency might be the key to ensuring the effectiveness of information obligations. 